\title{
Nitrogen and Phosphorus Changes in Soil and Soil Water after Cultivation
}

\author{
Mark Watkins, Hayley Castlehouse, Murray Hannah, and David M. Nash
}

Future Farming Systems Research Division, Department of Primary Industries, 1301 Hazeldean Road Ellinbank, VIC 3821, Australia

Correspondence should be addressed to David M. Nash, david.nash@dpi.vic.gov.au

Received 24 November 2011; Accepted 14 March 2012

Academic Editor: Rosario García Moreno

Copyright () 2012 Mark Watkins et al. This is an open access article distributed under the Creative Commons Attribution License, which permits unrestricted use, distribution, and reproduction in any medium, provided the original work is properly cited.

Untilled dairy pasture has the potential to release more phosphorus to the environment than a regularly ploughed pasture. In this paper we report the initial results of a study comparing the effects of cultivation, phosphorus (P) fertiliser (10, 35, and 100 kg P/ha), and two types of vegetation (ryegrass (Lolium perenne) or ryegrass mixed with clover (Trifolium repens)) in a randomised complete block design. Phosphorus was measured in soil samples taken from depths of 0-20 mm and 0-100 mm. Waters extracted from the 0-20 mm samples were also analysed. In all cases, the P concentrations (Olsen P, Colwell P, Total P, $\mathrm{CaCl}_{2}$ extractable P, Dissolved Reactive P, and Total Dissolved P) in the top $20 \mathrm{~mm}$ declined with ploughing. Dissolved Reactive P measured in the soil water was 70\% less overall in the ploughed plots compared with the unploughed plots, and by 35 weeks after P treatments the decrease in Dissolved Reactive P was 66\%. The effects of the fertiliser and pasture treatments were inconclusive. The data suggest that ploughing can lower the risk of $\mathrm{P}$ exports from intensive dairy farms in the trial area.

\section{Introduction}

Excessive phosphorus $(\mathrm{P})$ in surface waters is a major environmental issue in Australia [1]. In many freshwater ecosystems, $\mathrm{P}$ limits primary production and excessive $\mathrm{P}$ inputs contribute to eutrophication and the development of cyanobacterial blooms [2] which can be hazardous to human health [3-5]. This is especially true in the Gippsland Region of south-eastern Australia which contains the Tambo, Mitchell, Thomson, and Latrobe rivers and an estuarine lakes system of international significance, the Gippsland Lakes [6]. Agricultural enterprises, particularly dairy farms [7-9], contribute to excessive $\mathrm{P}$ concentrations and the associated increasing prevalence of algal blooms in the Gippsland Lakes $[10,11]$. For the Victorian coastal plains (Gippsland through to Melbourne at less than $200 \mathrm{~m}$ elevation), annual 75th percentile targets for total $\mathrm{P}(\mathrm{TP})$ and total nitrogen (TN) have been established for nutrients in rivers and streams; these targets are $0.045 \mathrm{mg} / \mathrm{L}$ and $0.6 \mathrm{mg} / \mathrm{L}$, respectively [12].

A broad range of strategies have been instigated to lessen $\mathrm{P}$ inflows to the Gippsland Lakes $[13,14]$. These strategies include on-farm measures such as minimising water lost to drains, construction of reuse ponds, stock exclusion from waterways, control of soil erosion, and management of fertiliser application and timing, as well as various offfarm measures to reuse irrigation drain water and minimise inputs from stream erosion, forestry activities, and industrial discharges. Prominent amongst these strategies has been the implementation of Best Management Practices (BMPs) to lessen dissolved $\mathrm{P}$ exports from dairy pastures. However, it is becoming increasingly clear that current BMPs [15] will not achieve the targeted $40 \%$ reduction [14] in P exports, especially from dairy farms.

Numerous studies have demonstrated that, surfaceapplied fertilisers, decaying plant material, and wastes from grazing animals increase $\mathrm{P}$ and $\mathrm{N}$ concentrations [16] and lower $\mathrm{P}$ adsorptive capacity in surface soils [17-20], thereby increasing $\mathrm{P}$ export potential $[21,22]$. Consequently, in wellmanaged dairy pastures in the Gippsland Region $\mathrm{P}$ and $\mathrm{N}$ are generally exported in dissolved $(<0.45 \mu \mathrm{m})$ rather than particulate forms $[9,17,23]$ with the times between fertiliser application and runoff, and grazing and runoff, and a yeardependant base component, explaining most of the between storm variation in $\mathrm{P}$ [24-26]. Cultivation is one way of lessening soil nutrient stratification, increasing $\mathrm{P}$ adsorption 


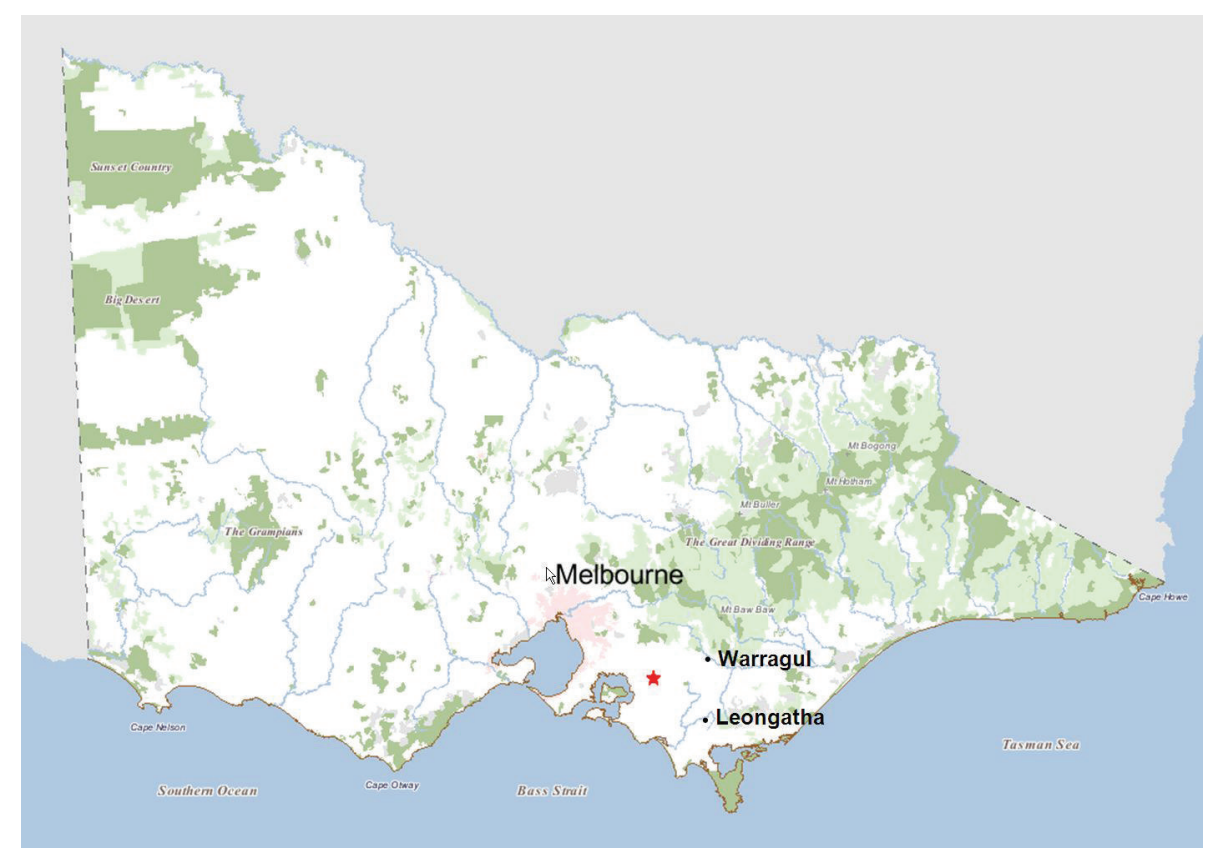

FIgUre 1: Location of the experimental site at Poowong, VIC, Australia.

near the soil surface and potentially lowering $\mathrm{P}$ exports [2730].

Studies on laser grading, an extreme form of cultivation, have been carried out in the Gippsland area. In the initial study, three years after laser grading, surface soil $\mathrm{P}$ adsorption had increased, soil test $\mathrm{P}$ decreased, soil water $\mathrm{P}$ and $\mathrm{N}$ concentrations decreased and total P (TP) and total N (TN) in irrigation runoff decreased by $41 \%$ and $36 \%$, respectively [31]. These studies were repeated on commercial farms. In the first year, cultivation had lowered soil and soil water $\mathrm{P}$ concentrations (in some cases by more than 50\%) and lowered $\mathrm{P}$ concentrations in runoff [32]. However, while the $\mathrm{P}$ export potential (estimated from soil tests) from cultivation remained lower for the duration of the study, albeit at a declining margin, there were no treatment effects on overland flow $\mathrm{P}$ concentrations after the first year. The lack of a treatment effect when the "background" sources of $\mathrm{P}$ in the soil had declined appears to be primarily the result of grazing effects and variability between sites, bays, and years, particularly during the drought experienced by this region at the time. There were no effects of cultivation on $\mathrm{N}$ exports in overland flow or soil water, presumably due to $\mathrm{N}$ fertiliser additions that continued during the study.

Pastures used for dairying in Gippsland are commonly a mix of ryegrass (Lolium spp.) and clover (Trifolium repens). Clover fixation of atmospheric nitrogen enhances soil $\mathrm{N}$ fertility, but clover requires a higher soil $\mathrm{P}$ (Olsen $\mathrm{P}$ of $>15 \mathrm{mg} / \mathrm{kg}$ ) compared with ryegrass (Olsen $\mathrm{P}>12 \mathrm{mg} / \mathrm{kg}$ ) $[33,34]$. This suggests that it may be possible to grow adequate ryegrass pasture at lower soil $\mathrm{P}$, and hence lower $\mathrm{P}$ export potential, if nitrogen fertiliser replaces the nitrogen fixing function of clover. The lower required soil P concentration would thereby enhance the benefits of cultivation in mitigating $\mathrm{P}$ exports. In this study we examined the effects of destratification of soils by mouldboard ploughing along with the effects of three $\mathrm{P}$ fertiliser application rates on pasture that is either a monoculture of ryegrass or mixed sward of ryegrass and clover. The quality and yield of the pasture were assessed for each treatment in addition to measures of $\mathrm{P}$ and $\mathrm{N}$ export potential.

It was hypothesised that $\mathrm{P}$ concentrations in the top $20 \mathrm{~mm}$ soil could be reduced by cultivation and that lower application of $\mathrm{P}$ fertiliser would reduce $\mathrm{P}$ in soil water. In addition, it was hypothesised that a ryegrass monoculture may be more viable than a ryegrass clover mix in a lower soil $\mathrm{P}$ environment and that differences in soil $\mathrm{N}$ and $\mathrm{P}$ may be observed between these two vegetative types.

\section{Method}

The experimental site was located near Poowong, Victoria, Australia $\left(-38.2782^{\circ}, 145.7404^{\circ}\right.$, Figure 1) in an undulating low hills landscape with a slope of $4 \%$. The soil type is typically a Grey Dermosol according to the Australian Soil Classification [35], but in poorer drained lower lying areas can be a Dermosolic Hydrosol (indicating that the soil profile is saturated for a number of months in most years). The surface soil texture is a light fine sandy clay loam. The average annual rainfall in the Poowong area is c. $1100 \mathrm{~mm}$ (30 year mean to 1991 is $1143 \mathrm{~mm}$ [36]). Rainfall and irrigation for the trial period are shown in Figure 2.

The experiment had a randomised complete block design with 12 treatments consisting of the complete factorial combinations of two types of sod preparation (mouldboard ploughed or unploughed), two types of vegetation (ryegrass monoculture or a mixed sward of white clover and ryegrass), and three rates of phosphorus fertiliser $(10,35,100 \mathrm{~kg} / \mathrm{ha})$. The trial site (c. 0.5 ha) was divided up into three blocks of 


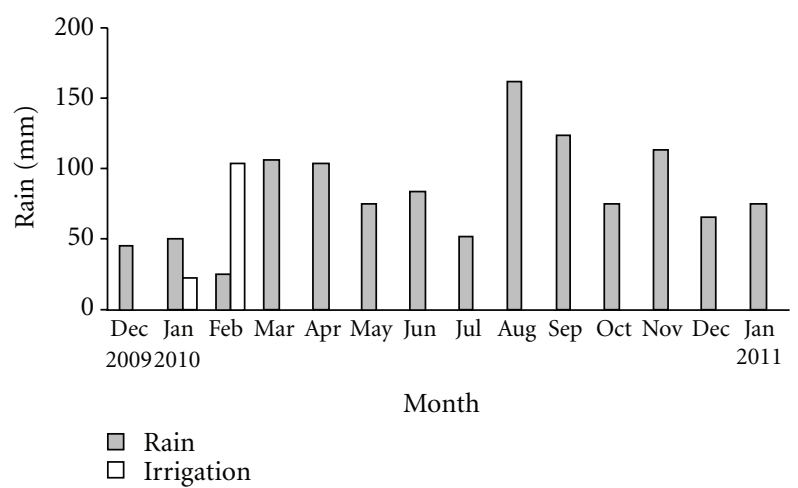

FIgURE 2: Monthly rainfall and irrigation for the trial period.

twelve plots $(12 \times 6 \mathrm{~m})$. Blocks were arranged with a $3 \mathrm{~m}$ buffer between each block.

Prior to treatment imposition, plots were sprayed with glyphosphate and heavily grazed to remove vegetation. Ploughed plots were mouldboard ploughed on November 20,2009 . As is common in the area, the ploughed plots were then levelled using a series of iron bars drawn behind a tractor on November 24, 2009. All plots were seeded the following day with $25 \mathrm{~kg} /$ ha perennial ryegrass (Lolium perenne) for the monoculture plots, and $25 \mathrm{~kg} / \mathrm{ha}$ ryegrass and $5 \mathrm{~kg} / \mathrm{ha}$ white clover (Trifolium repens, Kopu II) for the mixed sward plots. To aid establishment, a basal application of fertiliser was applied four weeks after ploughing at a rate of $15 \mathrm{~kg} / \mathrm{ha}$ P, $40 \mathrm{~kg} / \mathrm{ha} \mathrm{K}$ (Incitec Pivot SuperfectPot 2 and $1 \mathrm{Mo}: 5.9 \%$ P, $16.7 \% \mathrm{~K}, 7.3 \% \mathrm{~S}, 0.025 \% \mathrm{Mo}$ ) and $30 \mathrm{~kg} / \mathrm{haN}$ (Incitec Pivot granulated urea: $46 \% \mathrm{~N}$ ). Fertiliser P (Incitec Pivot Triple Super: $20.7 \%$ N, $1.0 \%$ S) treatments were applied on March 30, 2010. All plots received a basal fertiliser application for sulphur (60 kg/ha Gypsum) and potassium (Incitec Pivot Muriate of Potash $20 \mathrm{~kg} / \mathrm{ha}$ ) on the same day. Rust occurred in the ryegrass, and pure ryegrass plots subsequently received supplementary applications of urea to stimulate vegetative growth and alleviate the symptoms (February 4 and June 4, 2010). The herbicide MCPA (2-methyl-4chlorophenoxyacetic acid) was applied to ryegrass only plots to control unwanted paspalum on 26 March and 27 July 2010. MCPA could not be applied to the mixed sward plots as clover is sensitive to MCPA. It is of note that sowing was delayed due to wet conditions in late spring (which prevented ground preparation) and dry conditions during the summer of 2009-2010 necessitated irrigation to establish the pasture (122 mm applied in January and February 2010, Figure 2).

Commencing fifteen weeks after seeding, plots were grazed twelve times with 500 cows for an average of 45 minutes (i.e., until the animals stopped actively grazing). After grazing, manure was immediately removed by shovel from each plot to minimise the effects of manure on between plot and within plot variation. Where possible, on the following day remaining vegetation was mown to $80 \mathrm{~mm}$ pasture height to promote even growth in keeping with local farming practice [37]. A Gianni Ferrari GT20 catcher ride-on mower (JSB Equipment Pty Ltd, Carrum Downs, Australia) was used to cut the pasture and all grass clippings were removed off-site. Mowing was not possible between September 2010 and January 2011 due to very wet conditions and animal treading damage (i.e., pugging or poaching) which created an uneven soil surface. A roller was used to address these problems (December 23, 2010; January 15, 2011).

Soil was sampled at $0-20 \mathrm{~mm}$ and $0-100 \mathrm{~mm}$ depths from each plot after cultivation but before $\mathrm{P}$ fertiliser treatments were applied (November 4, 2009; March 10, 2010) and approximately quarterly thereafter (May 14, 2010, July 5, 2010, October 4, 2010, November 29, 2010). Additional samples from $0-300 \mathrm{~mm}$ deep were sampled annually (December 3, 2009, November 1, 2010). Samples were recovered from $20 \mathrm{~mm}$ and $100 \mathrm{~mm}$ depths at each sampling date using stainless steel corers $(25 \mathrm{~mm}$ ID). Samples to $300 \mathrm{~mm}$ were recovered using similar corers and sectioned $(0-20 \mathrm{~mm}, 20-50 \mathrm{~mm}, 50-75 \mathrm{~mm}, 75-100 \mathrm{~mm}$, $100-150 \mathrm{~mm}, 150-200 \mathrm{~mm}, 200-300 \mathrm{~mm}$ ) to yield seven samples per plot. Soils were not sampled in the four-week period following fertiliser application.

For the $20 \mathrm{~mm}$ sampling, a minimum of fifty cores from each plot were bulked to provide a composite sample which was subsequently used for both soil and soil water analyses. Ten cores from each plot were bulked to provide the $100 \mathrm{~mm}$ samples, while for the $300 \mathrm{~mm}$ samples five cores from each depth interval were bulked. All soil samples were returned to the laboratory in insulated containers $\left(5^{\circ} \mathrm{C}\right)$ where stones and large roots were removed and the samples thoroughly mixed. After mixing, a $50 \mathrm{~g}$ portion was taken from each sample to measure soil moisture and a $400 \mathrm{~g}$ portion of the $20 \mathrm{~mm}$ samples was taken for soil water analyses. The remaining soil was oven-dried at $40^{\circ} \mathrm{C}$ and sieved to $2 \mathrm{~mm}$. The dried, sieved soil was stored in polyethylene containers at room temperature prior to further analysis.

Soil moisture was determined at $105^{\circ} \mathrm{C}$. Soil samples were analysed for Olsen P, Colwell P, Calcium Chloride Extractable $\mathrm{P}\left(\mathrm{CaCl}_{2} \mathrm{P}\right)$, Total P (TP), Total N (TN), P Buffer Index with Colwell Fertility Correction $\left(\mathrm{PBI}_{+}\right.$ColP $)$, Skene Potassium (Skene K), Available Sulphur (CPC S, calcium phosphate plus charcoal extractable sulphur), Total Carbon (TC), and Oxidisable Organic Carbon (OOC, Walkley-Black method) [38]. Organic P was estimated as the additional $\mathrm{P}$ released after persulphate digestion of the Colwell $\mathrm{P}$ extract (LaChat Quickchem method 10-115-01-1-E, Hach, Loveland, CO, USA).

Soil water was extracted within 12 hours of sampling by centrifuging (GT20, Spintron Pty Ltd, Dandenong, Australia) $400 \mathrm{~g}$ of soil for 15 minutes at $1500 \mathrm{rpm}(500 \mathrm{~g}$ ) [39]. The soil water was then stored refrigerated $\left(4^{\circ} \mathrm{C}\right)$ in polypropylene containers (Techno Plas Pty Ltd, St Marys, Australia) prior to chemical analysis. Dissolved reactive P (DRP) was measured within 24 hours, while all other analyses were completed within 7 days. The samples were analysed using a LaChat Quickchem flow injection analyser, and QuikChem methods (Hach, Loveland, CO, USA). A portion of each sample was filtered through a $0.45 \mu \mathrm{m}$ membrane filter (Sartorius Minisart) for analysis of DRP (phosphoromolybdenum blue method 10-115-01-1-A), nitrate/nitrite ( $\mathrm{NO}_{x}$, cadmium reduction method 13-107-04-1-B), ammonia $\left(\mathrm{NH}_{3}\right.$, blue indophenol method 10-107-06-1-A), and 
TABLE 1: Initial soil properties two weeks prior to ploughing (November 2 and 5, 2009).

\begin{tabular}{|c|c|c|c|c|c|c|c|}
\hline & $\begin{array}{l}\text { Total N } \\
(\mathrm{mg} / \mathrm{kg})\end{array}$ & $\begin{array}{l}\text { Olsen P } \\
(\mathrm{mg} / \mathrm{kg})\end{array}$ & $\begin{array}{c}\text { Colwell P } \\
(\mathrm{mg} / \mathrm{kg})\end{array}$ & $\begin{array}{c}\text { Organic P } \\
(\mathrm{mg} / \mathrm{kg})\end{array}$ & $\begin{array}{l}\mathrm{CaCl}_{2} \mathrm{P} \\
(\mathrm{mg} / \mathrm{kg})\end{array}$ & $\begin{array}{c}\mathrm{NH}_{4}^{+} \\
(\mathrm{mg} / \mathrm{kg} \mathrm{N}) \\
\end{array}$ & $\begin{array}{c}\mathrm{NO}_{3}{ }^{-} \\
(\mathrm{mg} / \mathrm{kg} \mathrm{N})\end{array}$ \\
\hline \multicolumn{8}{|c|}{ 0-20 mm depth (November 2, 2009) } \\
\hline Mean & 5200 & 54 & 182 & 272 & 1.3 & 30 & 5.4 \\
\hline Minimum & 4400 & 34 & 100 & 160 & 0.2 & 11 & 0.5 \\
\hline Maximum & 6300 & 66 & 250 & 380 & 2.8 & 79 & 19 \\
\hline \multicolumn{8}{|c|}{ 0-100 mm depth (November 5, 2009) } \\
\hline Mean & 4400 & 41 & 132 & 208 & 0.7 & 20 & 7.3 \\
\hline Minimum & 3800 & 30 & 96 & 140 & 0.2 & 8.3 & 0.37 \\
\hline Maximum & 5600 & 54 & 180 & 290 & 1.5 & 60 & 27 \\
\hline \multicolumn{8}{|c|}{ Relative percentage difference of means comparing the $0-20 \mathrm{~mm}$ and $0-100 \mathrm{~mm}$ depths } \\
\hline & 18.8 & 32.4 & 38.3 & 30.8 & 78.2 & 48.4 & -26.0 \\
\hline
\end{tabular}

TDP (ammonium persulphate digestion followed by phosphomolybdenum blue method 10-115-01-1-E). Unfiltered samples were analysed for TP (ammonium persulphate digestion followed by phosphoromolydenum blue method 10-115-01-1-E) and TN (ammonium persulphate digestion followed by diazotised sulphanilamide with NED method 10107-04-1-A). Dissolved Unreactive P (DUP) was calculated as the difference between TDP and DRP; Particulate P (PP) was calculated as the difference in TP and TDP. Particulate N (PN) was calculated as the difference between TN and TDN, Dissolved Inorganic N (DIN) was calculated as the sum of ammonia and $\mathrm{NO}_{x}$, and Dissolved Organic Nitrogen (DON) was calculated as the difference between TDN and DIN.

Pasture samples were collected biannually (May 27, 2010, January 27, 2011) by mowing a diagonal strip with a Toro 20332 lawn mower (Toro Australia Pty. Ltd. Beverly, Australia) to $80 \mathrm{~mm}$ high with a catcher, tipping the contents onto a plastic tarpaulin, weighing the contents plus tarpaulin and then subsampling. The pasture was then freeze-dried (Dynavac FD600, Gardner Denver Industries Australia Pty Ltd, Dandenong South, Australia) except for a $1 \mathrm{~kg}$ portion which was dried at $60^{\circ} \mathrm{C}$ to determine dry matter. The freeze dried samples were stored at room temperature in polyethylene bags prior to analysis by near infrared reflectance spectrometry to determine protein, carbohydrate, fibre, fat, and energy (Dairy One, Ithaca, NY).

2.1. Statistical Methods. The effect of cultivation, vegetation, and $\mathrm{P}$ fertilising levels was analysed by ANOVA using Genstat (Release 13, 2010, VSN International Ltd, Hemel Hempstead, UK) statistical software. Treatment and blocking structures were as follows:

$$
\begin{gathered}
\text { Treatment: }(\text { Initial/(Sample Date } * \text { P Fertiliser Rate })) \\
* \text { Vegetation } * \text { Cultivation, } \\
\text { Block: Sample Date } *(\text { Block/Plot }),
\end{gathered}
$$

where " $*$ " is the crossing operator, and "/" is the nesting operator. The initial factor identifies samples taken before and after $\mathrm{P}$ fertiliser treatment. All samples were subsequent to cultivation treatment application and establishment of pastures. All data were checked for outliers and normality of distribution and constant variance using graphs of residuals versus fitted values, histograms and normal quantile plots of residuals. If necessary, data were transformed to meet distributional assumptions using a generalised log transformation:

$$
y=\ln (x+\sqrt{x+\lambda})
$$

where $x$ is the analyte concentration [40], the parameter $\lambda$ being estimated by maximum likelihood. Means were compared using least significant difference at the 5\% level. Back-transformed means were calculated $\left(x=\left[e^{y}-\right.\right.$ $\left.\left(\lambda / e^{y}\right)\right] / 2$ ) for presentation on the analyte concentration scale.

\section{Results and Discussion}

Monthly rainfalls during the trial period are shown in Figure 2. A total of $1151 \mathrm{~mm}$ fell over the trial area in 2010 . High rainfall in winter and spring caused waterlogging (i.e., saturation of the soil and standing water for $>10$ days on occasions) which are both characteristic of this area.

Soil test results prior to ploughing are presented in Table 1. Based on these results, the soil would be classified as having moderate to high soil $\mathrm{P}$ fertility [41] and moderate $\mathrm{P}$ sorption [42] which is typical of soils and farms in this region (John Gallienne, personal communication, June 2011). A comparison of the $0-20 \mathrm{~mm}$ and $0-100 \mathrm{~mm}$ soil test results suggests that prior to ploughing the soil had higher concentrations of $\mathrm{P}$ nearer the surface. For example, in the 0-20 $\mathrm{mm}$ and $0-100 \mathrm{~mm}$ depths, concentrations were 182 and $132 \mathrm{mg}$ Colwell P/kg, 54 and $41 \mathrm{mg}$ Olsen P/kg, 1.3 and $0.7 \mathrm{mg} \mathrm{CaCl} 2 \mathrm{P} / \mathrm{kg}$. Generally, $\mathrm{N}$ concentrations were also higher near the surface. For instance, $\mathrm{TN}$ and $\mathrm{NH}_{4}{ }^{+}$were 5.2 and $4.4 \mathrm{~g} \mathrm{~N} / \mathrm{kg}$, and 30 and $20 \mathrm{mg} \mathrm{N} / \mathrm{kg}$, respectively. However, $\mathrm{NO}_{3}{ }^{-}$concentration was lower at the $0-20 \mathrm{~mm}$ depth $(5.4 \mathrm{mg} \mathrm{N} / \mathrm{kg}$ ) compared to the $0-100 \mathrm{~mm}$ depth (7.3 $\mathrm{mg} \mathrm{N} / \mathrm{kg}$ ). This is possibly due to the effects of denitrification [43] and leaching [44] moving $\mathrm{N}$ to lower depths following high spring rainfall (November 2, 2011 for 0$20 \mathrm{~mm}$, November 5, 2010 for $0-100 \mathrm{~mm}$ ). The stratification at this site is similar to that measured in the Adelaide Hills, South Australia [17], but less than that measured on irrigated 
pastures of the Macalister irrigation district in south eastern Victoria, Australia [45]. This probably reflects prior fertiliser applications and operational management. The site for this study was a managed dairy pasture and, in the five years prior to this study being implemented, approximately $270 \mathrm{~kg} / \mathrm{ha}$ single superphosphate, $130 \mathrm{~kg} / \mathrm{ha}$ muriate of potash, and $100 \mathrm{~kg} / \mathrm{ha}$ of urea were applied annually.

After ploughing and sowing, but prior to the $\mathrm{P}$ treatments being implemented, surface soil water was sampled $(0-20 \mathrm{~mm})$. Ploughing lowered concentrations of $\mathrm{P}(P<$ $0.001)$ but increased concentrations of $\mathrm{N}(P<0.001)$. For example, DRP and TDP concentrations for ploughed and unploughed plots were 0.1 and $1.3 \mathrm{mg} / \mathrm{LDRP}$ and 0.6 and $3.3 \mathrm{mg} / \mathrm{L}$ TDP, respectively. The equivalent $\mathrm{N}$ data for ploughed and unploughed plots for concentrations were 60.0 and $30.5 \mathrm{mg} / \mathrm{L} \mathrm{N}$ for TDN, 10.9 and $2.8 \mathrm{mg} / \mathrm{L} \mathrm{N}$ for $\mathrm{NH}_{3}$, and 33.2 and $8.2 \mathrm{mg} / \mathrm{L} \mathrm{N}$ for $\mathrm{NO}_{x}$. Decreased $\mathrm{P}$ concentrations are consistent with other studies [18, 45-47] and probably reflect the relocation of topsoil away from the soil surface, in addition to increased $\mathrm{P}$ adsorption where ploughing brought fresh clay material to the surface. Increased $\mathrm{N}$ concentrations following ploughing are consistent with organic matter disturbance and aeration stimulating the microbial population resulting in increased ammonification and nitrification [48, 49].

Ploughing also affected soil water $\mathrm{P}$ tests after the $\mathrm{P}$ fertiliser treatments were applied $(P<0.001)$ for the subsequent four samplings (May 17, 2010, July 7, 2010, October 4, 2010, and November 29, 2010) (Table 2). For example, the mean DRP and TDP concentrations in ploughed and unploughed plots were 0.25 and $0.8 \mathrm{mg} / \mathrm{L} \mathrm{P}$, and 0.51 and $1.52 \mathrm{mg} / \mathrm{LP}$, respectively. Unlike the results prior to $\mathrm{P}$ fertiliser treatments being implemented, $\mathrm{N}$ concentrations were lower in the ploughed versus the unploughed plots (TDN, $P<0.001 ; \mathrm{NH}_{3}, P=0.014$; and $\mathrm{NO}_{x}, P=0.023$ ). Nitrogen concentrations for ploughed and unploughed plots were 10.0 and $13.1 \mathrm{mg} / \mathrm{L} \mathrm{N}$ for TDN, 0.4 and $0.5 \mathrm{mg} / \mathrm{L} \mathrm{N}$ for $\mathrm{NH}_{3}$, and 1.2 and $1.6 \mathrm{mg} / \mathrm{LN}$ for $\mathrm{NO}_{x}$. These results are consistent with ploughing having stimulated the rapid decomposition of organic matter, exhausting this source of $\mathrm{N}$ near the soil surface prior to the fertiliser treatments being initiated.

The results of the $0-20 \mathrm{~mm}$ soil testes were consistent with the soil water tests (Table 3). Olsen P, Colwell P, Organic $\mathrm{P}$, and $\mathrm{CaCl}_{2} \mathrm{P}$ concentrations decreased for ploughed versus unploughed plots $(P<0.001)$. The respective means were 35.8 and $66.4 \mathrm{mg} / \mathrm{kg} \mathrm{P}$ for Olsen $\mathrm{P}, 99.4$ and $205.4 \mathrm{mg} / \mathrm{kg} \mathrm{P}$ for Colwell P, 150.7 and $314.5 \mathrm{mg} / \mathrm{kg} \mathrm{P}$ for Organic P, and 0.50 and $1.8 \mathrm{mg} / \mathrm{L} \mathrm{P}$ for $\mathrm{CaCl}_{2} \mathrm{P}$.

There were no vegetation effects for the soil water. With the exception of $\mathrm{NH}_{4}{ }^{+}$, the same was true of the soil test results in the $0-20 \mathrm{~mm}$ soil samples. The concentration of $\mathrm{NH}_{4}{ }^{+}(P=0.003)$ was higher for the mixed sward plots $(11.0 \mathrm{mg} / \mathrm{kg} \mathrm{N})$ compared to the monoculture plots $(8.5 \mathrm{mg} /$ $\mathrm{kg} \mathrm{N}$ ). This was a surprising result as urea had been added to the ryegrass monoculture in response to the rust infestation. Presumably $\mathrm{NH}_{4}{ }^{+}$released from urea had been nitrified and leached from the profile prior to sampling, whereas $\mathrm{N}$ fixation by the clover in the mixed sward increased
$\mathrm{NH}_{4}{ }^{+}$concentrations as has also been reported to occur in Canterbury, New Zealand [50] and Terang, south-west Victoria [51].

Higher $\mathrm{P}$ fertiliser application rates increased the concentration of $\mathrm{P}$ in the soil water $(P<0.001)$. For example, at the fertilising rates of 10,35 and $100 \mathrm{~kg} / \mathrm{ha} \mathrm{P}$, concentrations were $0.27,0.36$, and $0.91 \mathrm{mg} / \mathrm{L}$ for $\mathrm{DRP}$, and $0.62,0.73$, and $1.52 \mathrm{mg} / \mathrm{L}$ for TDP. The results of the $0-20 \mathrm{~mm}$ soil tests results were consistent with the soil water tests $(P<0.001)$ as they increased in concentration with increased fertiliser rates. At fertiliser rates of 10,35 , and $100 \mathrm{~kg} / \mathrm{ha} \mathrm{P}$, the soil test concentrations were 512, 539 and $623 \mathrm{mg} \mathrm{TP} / \mathrm{kg}, 122,137$ and $198 \mathrm{mg}$ Colwell $\mathrm{P} / \mathrm{kg}, 41.4$, 46.2 and $65.6 \mathrm{mg}$ Olsen $\mathrm{P} / \mathrm{kg}$, 194, 217 and $287 \mathrm{~kg}$ Organic $\mathrm{P} / \mathrm{kg}$, and $0.66,0.83$ and $1.6 \mathrm{mg} \mathrm{CaCl}_{2} \mathrm{P} / \mathrm{kg}$, respectively. Similar trends have been found elsewhere $[8,9]$. In the same study, Robertson and Nash also found that $\mathrm{CaCl}_{2} \mathrm{P}$ concentrations were not always higher for higher $\mathrm{P}$ fertiliser rates and concluded that $\mathrm{CaCl}_{2} \mathrm{P}$ data would not be a useful environmental test in the pasture systems that they studied [8].

Over the period of four samplings after all treatments were implemented, $\mathrm{N}$ initially decreased and then tended to increase. For example, TDN $(P=0.001)$ concentrations over the four sampling dates were 19.91, 8.59, 9.35, and $10.77 \mathrm{mg} / \mathrm{L} \mathrm{N}$, and $\mathrm{NO}_{x}(P<0.001)$ concentrations were $4.39,1.77,0.41$, and $1.17 \mathrm{mg} / \mathrm{L} \mathrm{N}$. Concentrations of $\mathrm{NO}_{2}{ }^{-}$ $(P<0.001)$ remained unchanged. With the exception of DUP, which decreased over the first three samplings, and then doubled relative to the first sample $(0.39,0.29,0.04$, $0.77 \mathrm{mg} / \mathrm{L}$ DUP, $P=0.001)$, P concentrations decreased. The changes to DUP may in part be related to between sampling variation in the parameters from which it was derived. Another study [8], in which the highest fertiliser rate was only $23 \mathrm{~kg} \mathrm{P} / \mathrm{ha}$, also found DUP did not have a consistent trend with $\mathrm{P}$ fertilising rate. Over the same period, $0-20 \mathrm{~mm}$ soil test results for $\mathrm{P}, \mathrm{TN}$, and $\mathrm{NO}_{3}{ }^{-}$decreased $(P<0.001$ for Olsen $\mathrm{P}$, Colwell $\mathrm{P}$, and $\mathrm{NO}_{3}{ }^{-} ; \mathrm{P}=0.004$ for TN; and $P=0.002$ for Organic P). Sampling date did not affect $\mathrm{NH}_{4}{ }^{+}$which has also been reported occurring in simulated cultivation trials near Brisbane, Queensland [49].

Aside from the main treatment effects, after fertiliser treatments, there were also treatment interactions. For all soil water P analyses, there were Sample Date by P Fertiliser Rate interactions where decay rates decreased as the $\mathrm{P}$ fertiliser application rates were decreased $(P=0.02$ for TN, $P<0.001$ for others, see Figure 3). As has been seen previously with laser grading [32], a Sample Date by Cultivation interaction was also observed $(P<0.001)$ where the effects of cultivation diminished over time. For example, at the first sampling (May 17, 2011) after all treatments had been applied, the DRP concentration in the ploughed and unploughed plots was 0.40 and $2.36 \mathrm{mg} / \mathrm{L}$ while six months later (November 29,2010$)$ the concentrations had decreased to 0.10 and $0.31 \mathrm{mg} / \mathrm{L}$, respectively (Figure 3 ). TDP concentrations exhibited a similar trend except only the first three samplings showed a decrease in concentration. The fourth sample showed an increase in TDP concentrations, possibly due to waterlogging and pugging that occurred after the third sampling. A Vegetation by Cultivation interaction for both DIN 


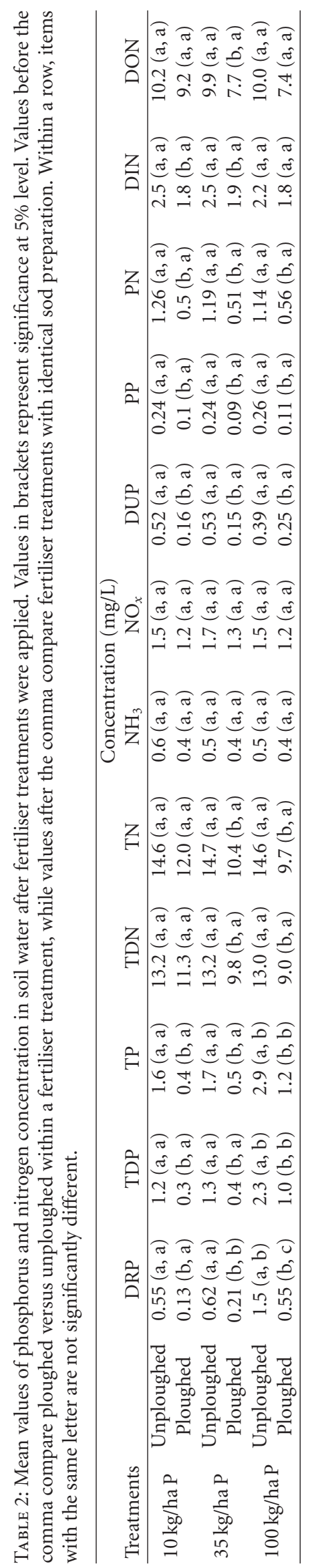


TABle 3: Mean values of soil fertility tests for both the $0-20 \mathrm{~mm}$ and $0-100 \mathrm{~mm}$ soil depths after fertiliser treatments were applied. Values in brackets represent significance at $5 \%$ level. Values before the comma compare ploughed versus unploughed within a fertiliser treatment, while values after the comma compare fertiliser treatments with identical sod preparation. Within a row, items with the same letter are not significantly different when comparing 0-20 mm together or comparing 0-100 mm together (significant tests have not been applied between different depths).

\begin{tabular}{|c|c|c|c|c|c|c|c|c|}
\hline \multirow{2}{*}{ Depth } & \multirow{2}{*}{ Treatments } & & \multicolumn{6}{|c|}{ Concentration $(\mathrm{mg} / \mathrm{kg})$} \\
\hline & & & Olsen P & Colwell P & Organic P & Total P & $\mathrm{CaCl}_{2} \mathrm{P}$ & $\mathrm{TN}$ \\
\hline \multirow{6}{*}{ Top $2 \mathrm{~cm}$} & \multirow{2}{*}{$10 \mathrm{~kg} / \mathrm{ha} \mathrm{P}$} & Unploughed & $58.6(\mathrm{a}, \mathrm{a})$ & $177(\mathrm{a}, \mathrm{a})$ & $281(\mathrm{a}, \mathrm{a})$ & $719(\mathrm{a}, \mathrm{a})$ & $1.5(\mathrm{a}, \mathrm{a})$ & $4600(a, a)$ \\
\hline & & Ploughed & $24.3(b, a)$ & $67.4(b, a)$ & $106(b, a)$ & $297(b, a)$ & $0.3(b, a)$ & $2320(b, a)$ \\
\hline & \multirow{2}{*}{$35 \mathrm{~kg} / \mathrm{ha} \mathrm{P}$} & Unploughed & $60.2(\mathrm{a}, \mathrm{a})$ & $187(\mathrm{a}, \mathrm{a})$ & $297(a, a)$ & $737(a, a)$ & $1.5(\mathrm{a}, \mathrm{a})$ & $4930(a, a)$ \\
\hline & & Ploughed & $32.2(b, a)$ & $86.8(\mathrm{~b}, \mathrm{a})$ & $137(b, a)$ & $330(b, a)$ & $0.5(\mathrm{~b}, \mathrm{~b})$ & $2280(b, a)$ \\
\hline & \multirow{2}{*}{$100 \mathrm{~kg} / \mathrm{ha} \mathrm{P}$} & Unploughed & $80.3(\mathrm{a}, \mathrm{b})$ & $252(a, b)$ & $365(a, a)$ & $799(a, a)$ & $2.9(\mathrm{a}, \mathrm{b})$ & $4600(a, a)$ \\
\hline & & Ploughed & $50.9(b, c)$ & $144(\mathrm{~b}, \mathrm{~b})$ & $209(b, b)$ & $441(\mathrm{~b}, \mathrm{~b})$ & $0.9(b, c)$ & $2440(\mathrm{~b}, \mathrm{a})$ \\
\hline \multirow{6}{*}{ Top $10 \mathrm{~cm}$} & \multirow{2}{*}{$10 \mathrm{~kg} / \mathrm{ha} \mathrm{P}$} & Unploughed & $42.9(\mathrm{a}, \mathrm{a})$ & $126(a, a)$ & $217(\mathrm{a}, \mathrm{ac})$ & $580(\mathrm{a}, \mathrm{a})$ & $0.6(a, a)$ & $4000(\mathrm{a}, \mathrm{ac})$ \\
\hline & & Ploughed & $28.9(b, a)$ & $83.3(\mathrm{~b}, \mathrm{a})$ & $145(b, a)$ & $360(b, b)$ & $0.5(\mathrm{a}, \mathrm{a})$ & $2700(b, a)$ \\
\hline & \multirow{2}{*}{$35 \mathrm{~kg} / \mathrm{ha} \mathrm{P}$} & Unploughed & $43.0(a, a)$ & $131(a, a)$ & $218(\mathrm{a}, \mathrm{bc})$ & $593(a, a)$ & $0.6(a, a)$ & $4200(a, a)$ \\
\hline & & Ploughed & $28.4(\mathrm{~b}, \mathrm{a})$ & $78.2(b, a)$ & $140(\mathrm{~b}, \mathrm{a})$ & $365(b, a)$ & $0.4(\mathrm{a}, \mathrm{a})$ & $2900(b, a)$ \\
\hline & \multirow{2}{*}{$100 \mathrm{~kg} / \mathrm{ha} \mathrm{P}$} & Unploughed & $49.3(\mathrm{a}, \mathrm{b})$ & $132(\mathrm{a}, \mathrm{a})$ & $225(a, a)$ & $468(a, a)$ & $0.7(a, a)$ & $3400(\mathrm{a}, \mathrm{bc})$ \\
\hline & & Ploughed & $40.4(\mathrm{~b}, \mathrm{~b})$ & $115(a, b)$ & $177(a, a)$ & $463(\mathrm{a}, \mathrm{a})$ & $0.5(\mathrm{a}, \mathrm{a})$ & $3200(a, b)$ \\
\hline
\end{tabular}

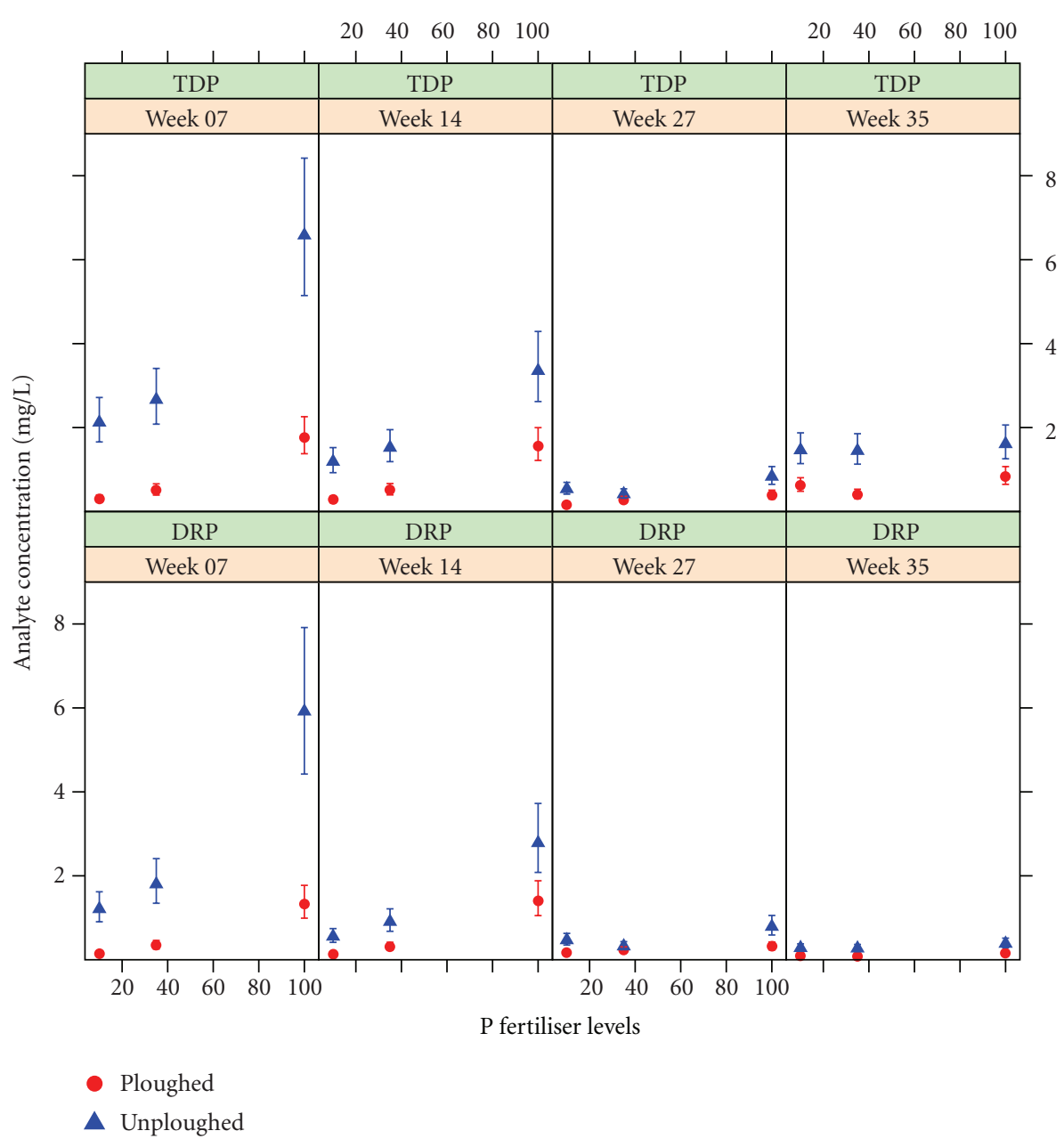

FIGURE 3: Mean TDP and DRP concentrations in soil water for ploughed and unploughed treatments at different P fertiliser levels showing the decay over the trial period. Week represents the number of weeks since fertiliser treatments began. Error bars represent significance at $5 \%$ level. 
TABLE 4: Mean pasture quality tests for vegetation treatments, sampled May 17, 2010.

\begin{tabular}{|c|c|c|c|c|c|c|}
\hline & \multirow[b]{2}{*}{ Yield $(\mathrm{kg} \cdot \mathrm{DM} / \mathrm{ha})$} & \multicolumn{5}{|c|}{ Dry matter basis } \\
\hline & & $\begin{array}{c}\text { Metabolisable energy } \\
(\mathrm{MJ} / \mathrm{kg})\end{array}$ & $\begin{array}{c}\text { Crude protein } \\
(\%)\end{array}$ & $\begin{array}{c}\text { Neutral detergent fibre } \\
(\%)\end{array}$ & $\begin{array}{c}\text { Starch } \\
(\%)\end{array}$ & Crude fat \\
\hline Monoculture & 474 & 10.4 & 22.5 & 48 & 0.5 & 5.6 \\
\hline Mixed sward & 535 & 11 & 25.8 & 43 & 1.9 & 5.3 \\
\hline Significance ( $P$ value $)$ & 0.008 & $<0.001$ & $<0.001$ & $<0.001$ & $<0.001$ & 0.019 \\
\hline
\end{tabular}

$(P=0.012)$ and $\mathrm{NO}_{x}(P=0.003)$ was also observed. DIN in the mixed sward plots accounted for the main cultivation effect, while the monoculture plots were unchanged between cultivation types. $\mathrm{NO}_{x}$ concentrations were similar, except that in the monoculture plots, unploughed plots had reduced $\mathrm{NO}_{x}$ concentrations versus ploughed plots, even though the mixed sward plots again accounted for the main cultivation effect. A marginal $(P=0.045)$ P Fertiliser by Cultivation interaction for DUP was observed with the interaction most evident at the $100 \mathrm{~kg} / \mathrm{ha} \mathrm{P}$ fertiliser application rate.

Except for $\mathrm{NH}_{4}{ }^{+}$or $\mathrm{NO}_{3}{ }^{-}$, the $0-20 \mathrm{~mm}$ soils test results had a similar Sample Date by Cultivation interaction $(P<$ $0.001)$ to the soil water analyses. For P and TN, the difference between ploughed and unploughed plots decreased over time. For example, Olsen $\mathrm{P}$ concentration in ploughed and unploughed plots was 41.95 and $87.44 \mathrm{mg} / \mathrm{kg}$ P in May 2010, and 30.8 and 51.9 in November 2010 .

The $0-100 \mathrm{~mm}$ soil tests had trends consistent with the 0 $20 \mathrm{~mm}$ soil tests (Table 2). At the $0-100 \mathrm{~mm}$ depth, TP, Colwell $\mathrm{P}$, Olsen $\mathrm{P}, \mathrm{CaCl}_{2} \mathrm{P}$ and $\mathrm{OOC}$ concentrations decreased with ploughing $(P<0.001)$. For example, in the ploughed and unploughed plots the mean concentrations were 396 and $547 \mathrm{mg} / \mathrm{kg}$ TP, 92.2 and $128.9 \mathrm{mg} / \mathrm{kg}$ Colwell $\mathrm{P}, 32.6$ and $45.1 \mathrm{mg} / \mathrm{kg}$ Olsen $\mathrm{P}, 0.4$ and $0.6 \mathrm{mg} / \mathrm{kg} \mathrm{CaCl} 2 \mathrm{P}$, and 7.1 and $9.4 \mathrm{mg} / \mathrm{kg}$ OOC, respectively. TN and $\mathrm{NH}_{4}{ }^{+}$concentrations also decreased with ploughing. For example, in the ploughed and unploughed plots the mean concentrations were 2.9 and $3.9 \mathrm{~g} / \mathrm{kg} \mathrm{TN}$, and 8.5 and $11.5 \mathrm{mg} / \mathrm{kg} \mathrm{NH}_{4}{ }^{+}$as N. Only Olsen $\mathrm{P}$ increased with $\mathrm{P}$ fertiliser application rate, and then only at the highest $\mathrm{P}$ fertiliser rate; the concentration of Olsen $\mathrm{P}$ was $35.6,35.7$, and $44.8 \mathrm{mg} / \mathrm{kg}$ at 10,35 , and $100 \mathrm{~kg} / \mathrm{ha} \mathrm{P}$, respectively.

The pasture results (May 17, 2010) are summarised in Table 4. Neutral Detergent Fibre (NDF) and Crude Fat (CF) were higher in the monoculture plots compared to the mixed sward plots (NDF, $P<0.001$; CF, $P=0.019$ ). For example, in the monoculture plots, NDF and CF concentrations were 47.9 and $5.6 \%$ (dry weight basis), and, in the mixed sward plots, the concentrations were 42.8 and 5.4\%. Other test results were higher in the mixed sward plots compared to the monoculture plots. For example, yield, metabolisable energy (ME), crude protein (CP) and starch concentrations on a dry matter basis in the monoculture plots were $474 \mathrm{~kg} \cdot \mathrm{DM} / \mathrm{ha}$, $10.4 \mathrm{MJ} / \mathrm{kg}$, and 22.5 and $0.5 \%$, while in the mixed sward plots the results were $535 \mathrm{~kg} \cdot \mathrm{DM} / \mathrm{ha}, 11.0 \mathrm{MJ} / \mathrm{kg}$, and 25.8 and $1.9 \%$. Ploughing lowered the concentration of CP $(P=$ 0.032). The mean CP concentration in the ploughed and unploughed plots was $23.7 \%$ and $24.5 \%$, respectively. This effect may be the result of reduced nitrogen in the top layer of soil given that nitrogen has a positive effect on CP [52]. However, such differences are biologically insignificant (B. Wales, personal communication 16-8-11) and cultivation effects or interactions may also be due to differences in establishment of the plots, such as weeds like paspalum that were more prevalent in the unploughed plots. There was a P Fertiliser by Cultivation effect $(P=0.025)$ where the concentration of CF increased with increases in $\mathrm{P}$ fertiliser rates for the ploughed plots but not for the unploughed plots. ME had a Vegetation by Cultivation interaction $(P=0.036)$ for mixed sward plots with the average ME concentration higher in the unploughed plots compared to the ploughed plots, but there was no significant difference between cultivation types for the monoculture plots. CF also had a Vegetation by Cultivation interaction $(P<0.001)$ where the concentration of CF in the monoculture plots was higher than the mixed sward plots for the cultivated treatments, but lower than the mixed sward plots in the uncultivated treatment.

Cultivation could be incorporated into farm management at times when pasture needs renovating or when a summer forage crop is to be planted. Generally, when pasture renovation is required, seed is over-sown into the pasture. Ploughing is not carried out, due to the added cost of seed bed preparation and the risk of erosion. However if soil $\mathrm{P}$ has built up in the upper layers, it could be environmentally advantageous to include ploughing to bury or mix the upper layer of soil with soil from lower in the profile. In doing so, the potential for soil erosion and consequent export of particulate $\mathrm{P}$ could potentially outweigh the advantage of ploughing to decrease dissolved $\mathrm{P}$ exports. For instance, ploughing would be too high a risk for steep hill slopes $(>5 \%)$, and renovation areas should only be performed when the potential for heavy precipitation is minimised (early autumn in Gippsland) (J. Gallienne, personal communication 17-11-11). In this study, a mouldboard plough was used rather than a power harrow which is more commonly used for commercial cultivation in the Gippsland. To destratify the soil $\mathrm{P}$, the upper soil layer must be either buried lower in the soil profile (e.g., mouldboard plough) or mixed in with the lower layers (e.g., rotary hoe). In contrast, some other types of cultivators (e.g., power harrow) would be less effective as they break up the soil but do not mix material in a vertical plane.

\section{Concluding Discussion}

As phosphorus exports from intensively grazed land are well above the $0.045 \mathrm{mg} / \mathrm{L} \mathrm{TP}$ objective values for Victorian coastal plains, mitigation measures need to be identified and 
implemented [12]. In this study, we compared potential $\mathrm{P}$ and $\mathrm{N}$ exports from a pasture soil from West Gippsland with higher $\mathrm{P}$, and generally higher $\mathrm{N}$ concentrations in the upper layer of soil. It is from this layer that the majority of $\mathrm{P}$ and $\mathrm{N}$ is mobilised into overland flow [53]. Cultivation mixed the upper nutrient rich layer further down the soil profile and brought up the less nutrient rich material to the surface. The concentrations of $\mathrm{P}$ and $\mathrm{N}$ in the upper $20 \mathrm{~mm}$ soil layer were lower in the ploughed treatments compared with the unploughed plots $(P<0.001)$. Cultivation also reduced the $\mathrm{P}$ and $\mathrm{N}$ concentrations in the soil water $(P<$ 0.001 for DRP, TDP, and TDN). Overall, mean soil water DRP concentration initially decreased by $70 \%$ by cultivation from $0.79 \mathrm{mg} / \mathrm{L}$ in the unploughed plots to $0.23 \mathrm{mg} / \mathrm{L}$ in the ploughed plots. At six months after treatments had been applied, the effect of ploughing on DRP, expressed as a percentage, was almost identical, 66\% (DRP means, unploughed plots: $0.31 \mathrm{mg} / \mathrm{L}$; ploughed plots: $0.10 \mathrm{mg} / \mathrm{L}$ ). Therefore, the cultivation undertaken potentially reduced the concentration of $\mathrm{P}$ that could be mobilised during overland flow events. Pasture type had no significant effect on the results after one year, although the mixed pasture had a higher yield and a higher quality feed than the monoculture plots.

Destratification by ploughing could be incorporated into farm management practice on occasions when pasture requires renovation, or a summer forage crop is to be planted. The cultivating machinery would need to mix or invert the soil in a vertical plane.

\section{Acknowledgments}

The authors would like to acknowledge the study was conducted on the property of Brett and Jodie Loughridge who provided enthusiastic help. The authors also wish to acknowledge the advice and monthly consultation with John Gallienne, agricultural consultant. The authors affirm they have no financial interest in the named products used, that is, Incitec Pivot fertilisers and Sartorius Minisart filters.

\section{References}

[1] J. R. Davis and K. Koop, "Eutrophication in Australian rivers, reservoirs and estuaries-a Southern hemisphere perspective on the science and its implications," Hydrobiologia, vol. 559, no. 1, pp. 23-76, 2006.

[2] M. R. Grace, T. R. Scicluna, C. L. Vithana, P. Symes, and K. P. Lansdown, "Biogeochemistry and cyanobacterial blooms: investigating the relationship in a shallow, polymictic, temperate lake," Environmental Chemistry, vol. 7, no. 5, pp. 443-456, 2010.

[3] V. May, "The occurance of toxic cyanophyte blooms in Australia," in The Water Environment: Algal Toxins and Health, W. W. Carmichael, Ed., pp. 127-142, Plenum, New York, NY, USA, 1981.

[4] I. R. Falconer, A. M. Beresford, and M. T. C. Runnegar, "Evidence of liver damage by toxin from a bloom of the blue-green alga, Microcystis aeruginosa," Medical Journal of Australia, vol. 1, no. 11, pp. 511-514, 1983.
[5] A. T. C. Bourke, R. B. Hawes, A. Neilson, and N. D. Stallman, "An outbreak of hepato-enteritis (the Palm Island mystery disease) possibly caused by algal intoxication," Toxicon, vol. 21, no. 3, pp. 45-48, 1983.

[6] P. Cottingham, G. Bennison, R. Dunn et al., Algal Bloom and Nutrient Status of Victorian Surface Waters, State Water Laboratory of Victoria, Melbourne, Australia, 1995.

[7] R. W. McDowell and R. J. Wilcock, "Water quality and the effects of different pastoral animals," New Zealand Veterinary Journal, vol. 56, no. 6, pp. 289-296, 2008.

[8] F. A. Robertson and D. M. Nash, "Phosphorus and nitrogen in soil, plants, and overland flow from sheep-grazed pastures fertilized with different rates of superphosphate," Agriculture, Ecosystems and Environment, vol. 126, no. 3-4, pp. 195-208, 2008.

[9] K. Barlow, D. M. Nash, and R. B. Grayson, "Phosphorus export at the paddock, farm-section, and whole farm scale on an irrigated dairy farm in South-Eastern Australia," Australian Journal of Agricultural Research, vol. 56, no. 1, pp. 1-9, 2005.

[10] I. T. Webster and Gippsland Coastal Board, Gippsland Lakes Environmental Study-Assessing Options for Improving Water Quality and Ecological Function, CSIRO Publishing, Collingwood, Australia, 2001.

[11] R. B. Grayson, K. S. Tan, and A. Western, Estimation of Sediment and Nutrient Loads into the Gippsland Lakes, CSIRO Publishing and University of Melbourne, Collingwood, Australia, 2001.

[12] Environment Protection Authority, Nutrient Objectives for Rivers and Streams-Ecosystem Protection, Environment Protection Authority, Melbourne, Australia, 2003.

[13] Department of Natural Resources and Environment, Macalister Irrigation District Nutrient Reduction Plan, Department of Natural Resources and Environment, Victoria, Australia, 1998.

[14] Environment Protection Authority, Protecting Water Quality in Central Gippsland. Schedule F5-Waters of the Latrobe and Thomson River Basins and Merriman Creek Catchment and Draft Policy Impact Assessment, Environment Protection Authority, Melbourne, Australia, 1995.

[15] T. Ladson and J. Tilleard, BMPs for Reducing Phosphorus Loads to the Gippsland Lakes, Report on Findings from Expert Panel, Gippsland Lakes Task Force, 2006.

[16] E. Frossard, L. M. Condron, A. Oberson, S. Sinaj, and J. C. Fardeau, "Processes governing phosphorus availability in temperate soils," Journal of Environmental Quality, vol. 29, no. 1, pp. 15-23, 2000.

[17] W. J. Dougherty, D. M. Nash, D. J. Chittleborough, J. W. Cox, and N. K. Fleming, "Stratification, forms, and mobility of phosphorus in the topsoil of a Chromosol used for dairying," Australian Journal of Soil Research, vol. 44, no. 3, pp. 277-284, 2006.

[18] N. J. Mathers and D. M. Nash, "Effects of tillage practices on soil and water phosphorus and nitrogen fractions in a Chromosol at Rutherglen in Victoria, Australia," Australian Journal of Soil Research, vol. 47, no. 1, pp. 46-59, 2009.

[19] A. N. Sharpley, S. J. Smith, and W. R. Bain, "Nitrogen and phosphorus fate from long-term poultry litter applications to Oklahoma soils," Soil Science Society of America Journal, vol. 57, no. 4, pp. 1131-1137, 1993.

[20] J. T. Sims, R. R. Simard, and B. C. Joern, "Phosphorus loss in agricultural drainage: Historical perspective and current research," Journal of Environmental Quality, vol. 27, no. 2, pp. 277-293, 1998. 
[21] S. T. Pierson, M. L. Cabrera, G. K. Evanylo et al., "Phosphorus and ammonium concentrations in surface runoff from grasslands fertilized with broiler litter," Journal of Environmental Quality, vol. 30, no. 5, pp. 1784-1789, 2001.

[22] D. H. Pote, T. C. Daniel, D. J. Nichols et al., "Relationship between phosphorus levels in three ultisols and phosphorus concentrations in runoff," Journal of Environmental Quality, vol. 28, no. 1, pp. 170-175, 1999.

[23] D. M. Nash and C. Murdoch, "Phosphorus in runoff from a fertile dairy pasture," Australian Journal of Soil Research, vol. 35, no. 2, pp. 419-429, 1997.

[24] D. M. Nash, L. Clemow, M. Hannah, K. Barlow, and P. Gangaiya, "Modelling phosphorus exports from rain-fed and irrigated pastures in Southern Australia," Australian Journal of Soil Research, vol. 43, no. 6, pp. 745-755, 2005.

[25] D. M. Nash, M. Hannah, D. Halliwell, and C. Murdoch, "Factors affecting phosphorus export from a pasture-based grazing system," Journal of Environmental Quality, vol. 29, no. 4, pp. 1160-1166, 2000.

[26] D. M. Nash and M. Hannah, "Using Monte-Carlo simulations and Bayesian Networks to quantify and demonstrate the impact of fertiliser best management practices," Environmental Modelling and Software, vol. 26, no. 9, pp. 1079-1088, 2011.

[27] J. E. Morrison and F. W. Chichester, "Tillage system effects on soil and plant nutrient distributions on vertisols," Journal of Production Agriculture, vol. 7, no. 3, pp. 364-373, 1994.

[28] B. Pezzarossa, M. Barbafieri, A. Benetti et al., "Effects of conventional and alternative management systems on soil phosphorus content, soil structure, and corn yield," Communications in Soil Science and Plant Analysis, vol. 26, no. 17-18, pp. 2869-2885, 1995.

[29] G. W. Rehm, G. W. Randall, A. J. Scobbie, and J. A. Vetsch, "Impact of fertilizer placement and tillage system on phosphorus distribution in soil," Soil Science Society of America Journal, vol. 59, no. 6, pp. 1661-1665, 1995.

[30] A. N. Sharpley, "Soil mixing to decrease surface stratification of phosphorus in manured soils," Journal of Environmental Quality, vol. 32, no. 4, pp. 1375-1384, 2003.

[31] D. M. Nash, B. Webb, M. Hannah et al., "Changes in nitrogen and phosphorus concentrations in soil, soil water and surface run-off following grading of irrigation bays used for intensive grazing," Soil Use and Management, vol. 23, no. 4, pp. 374-383, 2007.

[32] D. M. Nash and H. Castlehouse, "Improved grazing systems that enhance water quality (phase 2)," Final Report, 2009.

[33] Pastures Australia, White Clover, 2011, http://www.pasturepicker.com.au/Html/White_clover.htm.

[34] Pastures Australia, Perennial Ryegrass, 2011, http://www.pasturepicker.com.au/Html/Perennial_ryegrass.htm.

[35] R. F. Isbell, Australian Soil Classification, CSIRO Publishing, Collingwood, Australia, 2002.

[36] Commonwealth of Australia, B.o.M. Monthly rainfall, Poowong (Post Office), 2011, http://reg.bom.gov.au/jsp/ncc/cdio/ weatherData/av?p_nccObsCode=139\&p_display_type $=$ dataFile\&p_stn_num=086092.

[37] F. Tyndall, Grazing Dairy Pastures, Department of Natrual Resources and Environment, Victorian State Government, Victoria, Australia, 2002.

[38] G. E. Rayment and D. J. Lyons, Soil Chemical MethodsAustralasia, CSIRO Publishing, Collingwood, Australia, 2011.

[39] M. Toifl, D. Nash, F. Roddick, and N. Porter, "Effect of centrifuge conditions on water and total dissolved phosphorus extraction from soil," Australian Journal of Soil Research, vol. 41, no. 8, pp. 1533-1542, 2003.
[40] D. M. Rocke, B. Durbin, M. Wilson, and H. D. Kahn, "Modeling uncertainty in the measurement of low-level analytes in environmental analysis," Ecotoxicology and Environmental Safety, vol. 56, no. 1, pp. 78-92, 2003.

[41] K. I. Peverill, L. A. Sparrow, and D. J. Reuter, Eds., Soils Analysis: An Interpretation Manual, CSIRO Publishing, Collingwood, Australia, 1999.

[42] L. L. Burkitt, P. W. Moody, C. J. P. Gourley, and M. C. Hannah, "A simple phosphorus buffering index for Australian soils," Australian Journal of Soil Research, vol. 40, no. 3, pp. 497-513, 2002.

[43] E. W. Russell, Soil Conditions and Plant Growth, Longman, 10th edition, 1973.

[44] D. M. Nash, D. Halliwell, and J. Cox, "Hydrological mobilisation of pollutants at the slope/field scale," in Agriculture, Hydrology and Water Quality, P. M. Haygarth and S. C. Jarvis, Eds., pp. 225-242, CABI Publishing, Oxon, UK, 2002.

[45] D. M. Nash, B. Webb, M. Hannah et al., "Changes in nitrogen and phosphorus concentrations in soil, soil water and surface run-off following grading of irrigation bays used for intensive grazing," Soil Use and Management, vol. 23, no. 4, pp. 374-383, 2007.

[46] A. N. Sharpley, "Soil mixing to decrease surface stratification of phosphorus in manured soils," Journal of Environmental Quality, vol. 32, no. 4, pp. 1375-1384, 2003.

[47] D. T. Vu, C. Tang, and R. D. Armstrong, "Tillage system affects phosphorus form and depth distribution in three contrasting Victorian soils," Australian Journal of Soil Research, vol. 47, no. 1, pp. 33-45, 2009.

[48] A. L. Heathwaite, P. J. Johnes, and N. E. Peters, "Trends in nutrients," Hydrological Processes, vol. 10, no. 2, pp. 263-293, 1996.

[49] P. R. Grace, I. C. MacRae, and R. J. K. Myers, "Temporal changes in microbial biomass and $\mathrm{N}$ mineralization under simulated field cultivation," Soil Biology and Biochemistry, vol. 25, no. 12, pp. 1745-1753, 1993.

[50] W. R. Cookson, I. S. Cornforth, and J. S. Rowarth, "Winter soil temperature $\left(2-15^{\circ} \mathrm{C}\right)$ effects on nitrogen transformations in clover green manure amended or unamended soils; a laboratory and field study," Soil Biology and Biochemistry, vol. 34, no. 10, pp. 1401-1415, 2002.

[51] F. R. McKenzie, J. L. Jacobs, P. Riffkin, G. Kearney, and M. McCaskill, "Long-term effects of multiple applications of nitrogen fertiliser on grazed dryland perennial ryegrass/white clover dairy pastures in south-west Victoria. 1. Nitrogen fixation by white clover," Australian Journal of Agricultural Research, vol. 54, no. 5, pp. 461-469, 2003.

[52] F. R. McKenzie, J. L. Jacobs, M. J. Ryan, and G. Kearney, "Effect of rate and time of nitrogen application from autumn to midwinter on perennial ryegrass-white clover dairy pastures in Western Victoria. 2. Pasture nutritive value," Australian Journal of Agricultural Research, vol. 50, no. 6, pp. 1067-1072, 1999.

[53] L. R. Ahuja and O. R. Lehman, "The extent and nature of rainfall-soil interaction in the release of soluble chemicals to runoff," Journal of Environmental Quality, vol. 12, no. 1, pp. 34-40, 1983. 

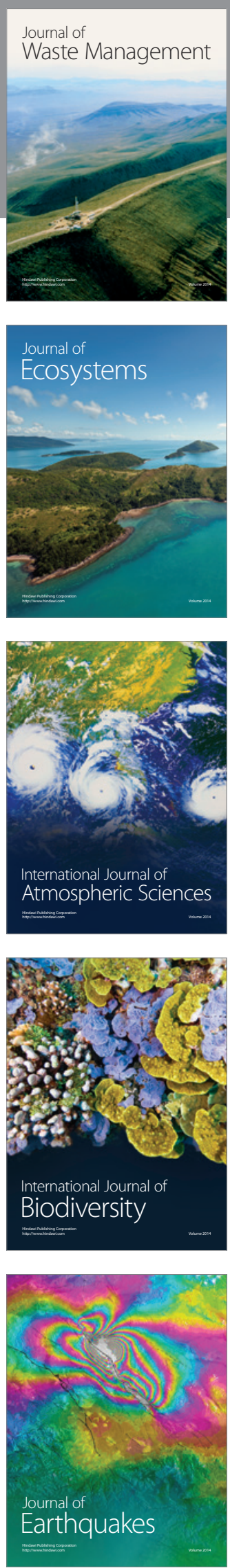
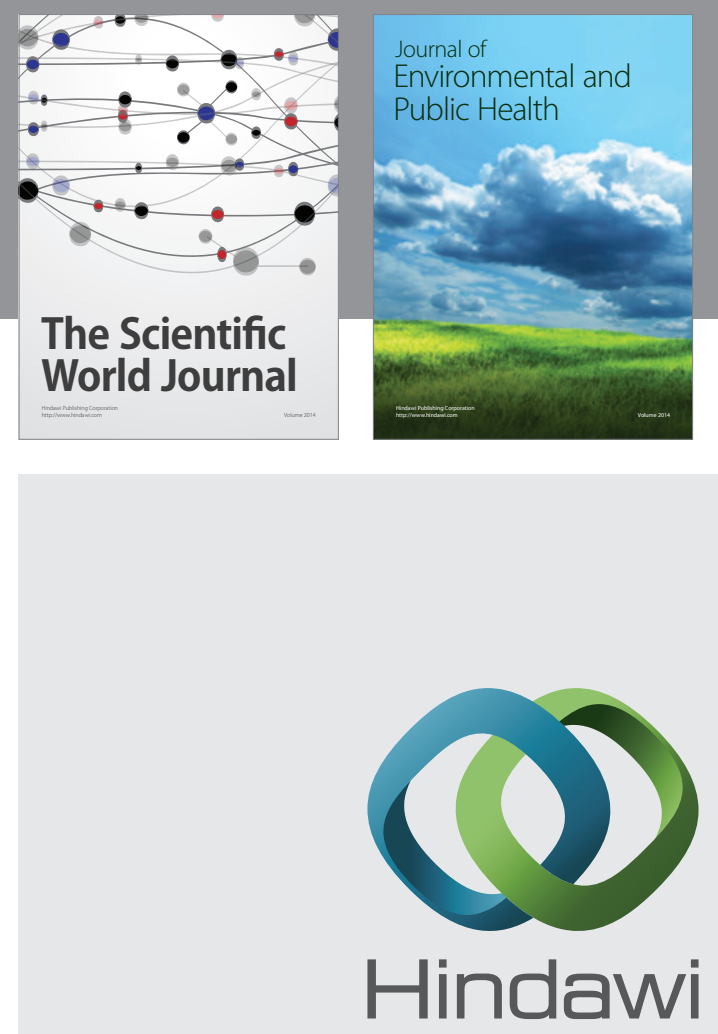

Submit your manuscripts at

http://www.hindawi.com
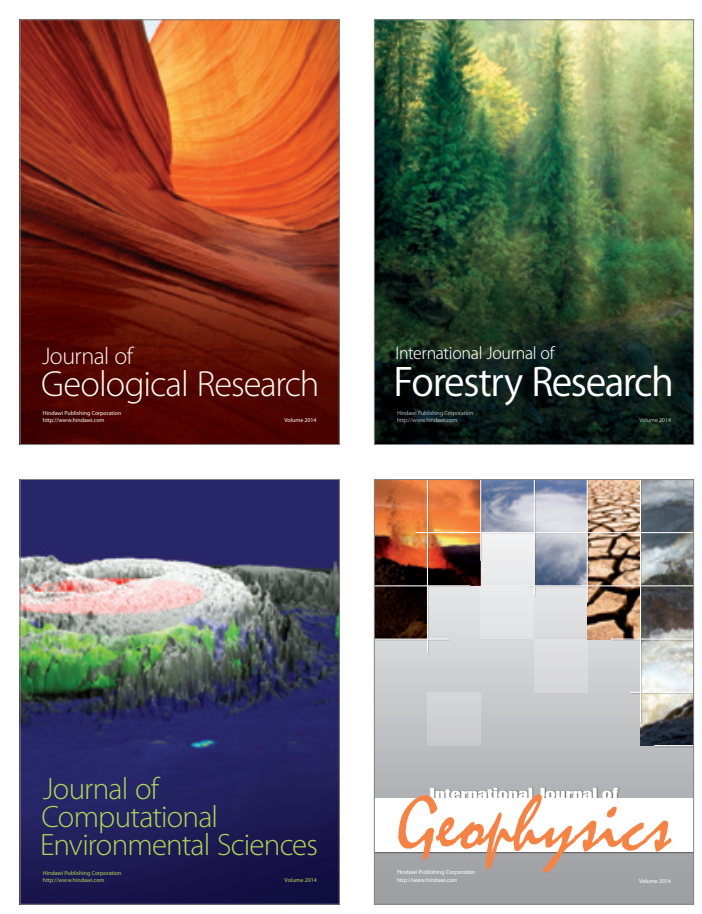
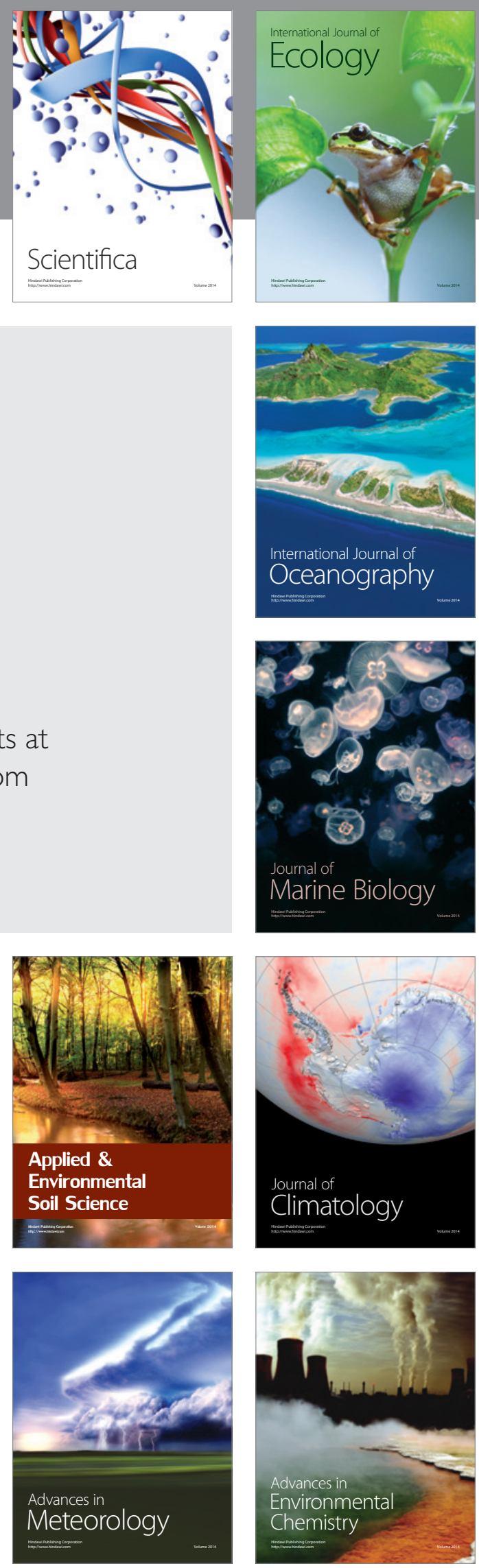